\title{
Pygopus (Squamata: Pygopodidae) from mid-Holocene cave deposits, Western and South Australia
}

\author{
Jim I. Mead ${ }^{1,3,}$, Marci Hollenshead ${ }^{2.3}$, Sandra L. Swift ${ }^{3 *}$, Christopher J. Bell ${ }^{4}$ and Alexander Baynes \\ 'Department of Geology, Northern Arizona University, Flagstaff, Arizona 86011 USA; E-mail: James. Meadenauedu; \\ 'Department of Biological Sciences, Northern Arizona University, Flagstaff, Arizona 86011 USA. \\ 'Laboratory of Quaternary Paleontology, Center for Environmental Sciences and Education, \\ Northem Arizona University. Flagstaff, Arizona 86011 USA. \\ Department of Geological Sciences, The Jackson School of Geosciences, \\ University of Texas at Austin, Austin, Texas 78712 USA.
}

Department of Earth and Planetary Sciences, Western Australian Muscum,

Locked Bag 49, Welshpool DC, WA 6986 Australia.

Present address: Department of Geosciences, East Tennessee State University,

Johnson City, Tennessee 37614 USA. E-mail: mead actsuedu

\begin{abstract}
We report fossil remains of pygopodid lizards of known or probable Holocene deposits in Webbs Cave in Western Australia and Wombat Cave in South Australia. Knowledge of patterns of skeletal variation within and across pygopodid groups is insufficiently mature to permit species-level resolution. Confident identification of apomorphies to diagnose our specimens is limited by a general paucity of skeletal preparations of pygopodids. Preserved anatomical features on the fossils are interpreted in the context of published literature and putative apomorphies, and permit referral to the genus Pygopus. These specimens represent important additional records of Pygopus, and contribute to an improved understanding of the evolution of faunal communities in the Holocene of western and southern Australia.
\end{abstract}

\section{INTRODUCTION}

Several cave deposits in Western Australia were excavated since the 1950 s for late Quaternary mammalian and archaeological remains, and produced a rich palaeontological record (Lundelius 1960; Dortch 1996, 2004). Marsupials and rodents were the focus of many of these studies, and extinctions and changes in their relative abundances through time are well documented. These changes serve as climatic proxies or to document zoogeographic range variations (Lundelius 1960, 1983; Balme et al. 1978; Baynes 1982). Squamate remains from these deposits also are abundant but have yet to be systematically studied in detail. Here we report the occurrence of pygopodid lizard remains recovered from cave deposits at Webbs and Wombat caves (Hampton Tableland).

Pygopods (flap-footed lizards) are a family of gekkonoid lizards endemic to Australia and New Guinea (Shea 1993). Over 38 species are currently recognized within the family, and are classified in seven genera (Aprasia, Delma, Lialis, Ophidiocephalus, Paradelma, Pletholax, and Pygopus; Jennings et al. 2003; Han et al. 2004; Maryan et al. 2007). Pygopods occur throughout most of Australia except for Tasmania, extreme southeastern Australia, and the rainforests of the northeast (Shea 1993). Although today they are widespread throughout most of the continent, their fossil record is extremely sparse, with only one known fossil from the Miocene of Riversleigh, northwestern Queensland (Hutchinson 1997). Estimates of divergence times and mode of evolution and dispersal for the group are based mostly on inference from molecular data sets and tree topologies (e.g. Jennings et al. 2003).

Although superficially snake-like in appearance, pygopods retain a pectoral girdle with no external vestiges of front limbs and a pelvic girdle occasionally with hind limb remnants (Greer 1989; Shea 1993). Based on a sequence of molecular data (12S rRNA and c-mos) Donnellan et al. (1999) support the concept that Pygopodidae and Diplodactylidae are sister taxa. Similarly, the most recent taxonomic treatments recognize a monophyletic Pygopodidae as sister taxon to Diplodactylidae (Russell and Bauer 2002) or as sister to the padless Australian carphodactylines (Han et al. 2004). However, details of cranial osteology and myology are presently ambiguous in supporting a definitive sister-taxon relationship between pygopods and other groups of gek konoids (e.g. Kluge 1987; Estes et al. 1988; Röll and Henkel 2002). The historical uncertainty of higher-level 
relationships of pygopods contributed to a variable taxonomy for the pygopods and diplodactyline geckos (see differing views in Kluge 1987; Bauer 1990; King and Mengden 1990; Hutchinson 1997).

\section{CAVE DEPOSITS}

\section{Webbs Cave}

Webbs Cave (6N 132; Western Australia; Figure 1) is situated on the Hampton Tableland south of the Nullarbor Plain at $31^{\circ} 46^{\prime} \mathrm{S}, 127^{\circ} 48^{\prime} \mathrm{E}$, approximately $9.5 \mathrm{~km}$ north of Mundrabilla homestead. The entrance is an open, shallow sinkhole with abundant skeletal remains under overhangs. Passages go to small chambers with bones and speleothems; these chambers are ultimately terminated by roof collapse (Lundelius 1963; E. L. Lundelius field notes, May 1964; Vertebrate Paleontology Laboratory, Texas Natural Science Center, The University of Texas at Austin). Sixteen species of fossil mammals were recorded from the cave by Baynes (1987).

On top of a large collapse-boulder in the entrance sinkhole are many years of bone and sediment accumulation, and it is here that E. L. Lundelius recovered a Sarcophilus (Tasmanian devil) premolar in 1955 and conducted excavations in 1964. Bulk samples of bones and sediments were removed from five depth intervals. These were originally recorded in inches as $0-3,3-6,6-9,9-12$, and 12-15 inches below surface but are here treated as their metric equivalents of $0-7.5,7.5-15.0,15.0$ $23.0,23.0-30.5,30.5-38.0 \mathrm{~cm}$, respectively. All sieved residue, charcoal, and bones are curated at the Texas Memorial Museum, Vertebrate Paleontology Laboratory, The University of Texas at Austin (TMM).

The principal agents of bone accumulation in the Nullarbor and Hampton Tableland caves were Tyto alba, T. novaehollandiae (masked owl) and Falco cenchroides (Australian kestrel; Baynes 1987). Lizard remains were common throughout the Webbs Cave sedimentary deposit. Two pygopod dentaries were recovered from the $15.0-23.0 \mathrm{~cm}$ and $30.5-38.0 \mathrm{~cm}$ intervals. Charcoal from the $15.0-23.0$ $\mathrm{cm}$ interval produced an AMS radiocarbon intercept age of Cal BP 4,160 (Beta-214963), and represents a mid-Holocene record. With an assumption of a constant deposition rate, the skeletal remains in the undated $30.5-38.0 \mathrm{~cm}$ interval would be approximately 5,200 years old.

\section{Wombat Cave}

Wombat Cave (5N 264) is located approximately $42 \mathrm{~km}$ west of Koonalda on the Hampton Tableland in western-most South Australia (Figure 1). This small cavern has a low arched roof and three entrances, each with an associated debris cone. The

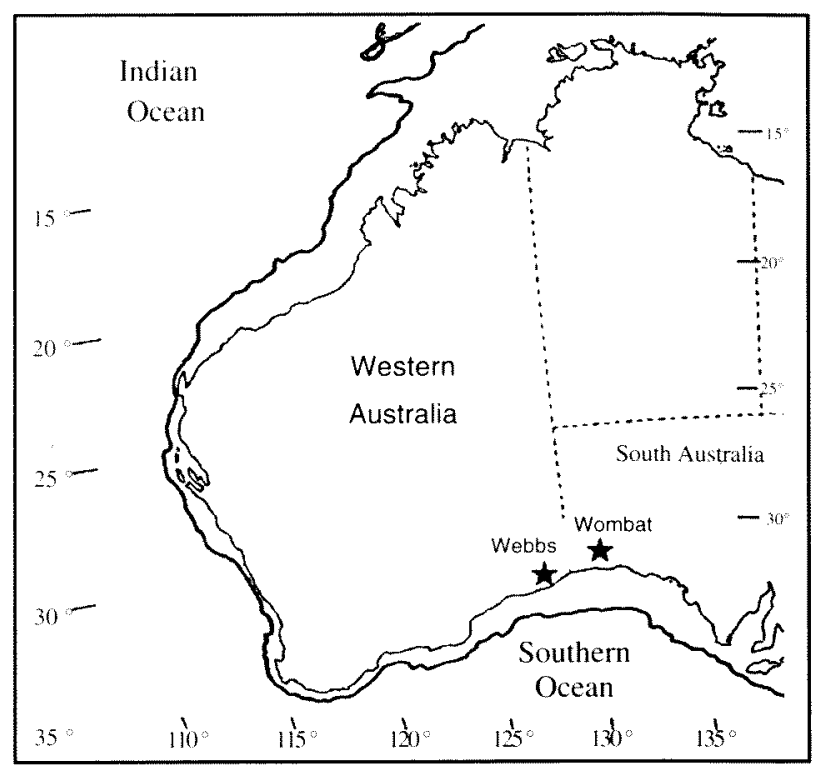

Figure 1 Map of Western Australia and adjacent regions showing the locations of Webbs and Wombat caves from which mid-Holocene Pygopus sp. lizard remains were collected. Heavy line represents the coastline position during the full glacial low-stand sea level (adapted from Dortch 1996).

basal edges of the debris cones are buried by reddish-brown silt of unknown age. The reddishbrown silt continues to a depth of about $92 \mathrm{~cm}$ (originally determined as 36 inches). Lasiorhinus latifrons (southern hairy-nosed wombat) dug extensively into this silt layer. Abruptly below the reddish-brown silt is a brighter red sand and clay unit (that shows no sign of wombat burrowing or bioturbation) containing limestone boulders and skeletal remains (E. L. Lundelius field notes, May 1964). Lizard remains, including one pygopod specimen, were recovered from 92-106 cm below surface, in the lower red sand and clay unit. The pygopod specimen from this lower unit is clearly not modern based on stratigraphic placement. The actual age is not known but is presumed to be from the Holocene, if not late Pleistocene. Clearly more work is needed in this cave. All fossils recovered by E. L. Lundelius in 1964 are curated in TMM.

\section{Pygopod remains}

Relatively few publications specifically address the osteology of pygopodid lizards. General aspects of skeletal morphology were discussed by Camp (1923; Lialis; Pygopus), Stokely (1947; Aprasia), Parker (1956; Aprasia), Underwood (1957; Aprasia, Delma, Lialis, Pygopus) and Moffat (1973; Aprasia, Delma, Lialis, Pletholax, Pygopus). Pectoral and pelvic girdle morphology were discussed by Fürbringer (1870; Lialis, Pygopus), Cope (1892; Pygopus) and Stephenson (1962; Aprasia, Delma, Lialis, Pletholax, Pygopus). General features of the 
skull were noted by Kinghorn (1926) and Bellairs and Kamal (1981); more extensive coverage of particular taxa was provided by Jensen (1901; Aprasia), Kinghorn (1923; Aprasia), Broom (1935; Pygopus), McDowell and Bogert (1954; Aprasia, Delma, Lialis, Pygopus), Stephenson (1962; Aprasia, Delma, Lialis, Pletholax, Pygopus) and Rieppel (1984b; Aprasia, Pletholax, Pygopus). Detailed description of mandibular morphology was summarized by Hutchinson (1997). Additional published osteological data sets include vertebral morphology (Etheridge 1967; Hoffstetter and Gasc 1969), scleral ring formulae (Underwood 1970; Aprasia, Delma, Lialis, and Pygopus), and the detailed information on specific anatomical regions of the skeleton provided by Kluge (1976, 1987), Rieppel (1984a), and Lee (1998) as part of their phylogenetic studies of the group.

Our analysis of the pygopodid fossil remains is based primarily on published descriptions by Hutchinson (1997) and comparisons made with modern skeletal material. Identifications are based on morphological characters observed on modern specimens; an apomorphy-based approach was not possible because sufficiently detailed analyses of isolated skeletal elements of all pygopodids and their outgroups have yet to be conducted, and adequate skeletal collections of Australian gekkotans are lacking. Possible apomorphies are identified, and are combined with characters (the apomorphic status of which is not confirmed) that appear to exclude referral to one or other pygopod taxa. This approach permits referral to genus for all fossils considered here. We made no attempt to identify specimens to the species level.

\section{Webbs Cave}

One right dentary (TMM 41209-964; 15.0-23.0 cm interval) and one left dentary (TMM 41209-965; $30.5-38.0 \mathrm{~cm}$ interval) were recovered (Figure 2A, B). Both are complete and have the same osteological features. The groove for the Meckelian cartilage is completely enclosed by bone (a universal feature within gekkonoids, but also present in all dibamids and xantusiids, and variably present within gymnophthalmids, scincids, many non-acrodont iguanian groups and some amphisbaenians (Greer 1970; MacLean 1974; Gans 1978; Estes et al. 1988; Etheridge and de Queiroz 1988; Bell et al. 2003). The angular process of each dentary is near-complete and positioned well posterior of the coronoid. The intramandibular septum is not extended posteriorly. The fossils do not belong to Aprasia, Ophidiocephalus, or Pletholax because the anterior contact for the splenial is ventral to the four posterior-most tooth positions. Loci for up to 15 teeth are present. The teeth are robust and each has an apical groove (see discussion in Sumida and Murphy 1987 and Hutchinson 1997). The posterior edge of the tooth row is raised dorsally to meet a high coronoid, a character found only in Pygopus. Teeth decrease in size and robustness from mesial to distal position. These features (possible apomorphies) on the two dentaries indicate that they belong to Pygopus.

\section{Wombat Cave}

A posterior fragment of a right dentary (TMM 41374-1 Figure 2C) was recovered from the red sand and clay unit at $92-106 \mathrm{~cm}$ below surface. The angular process of the dentary is near-complete and

\section{A}

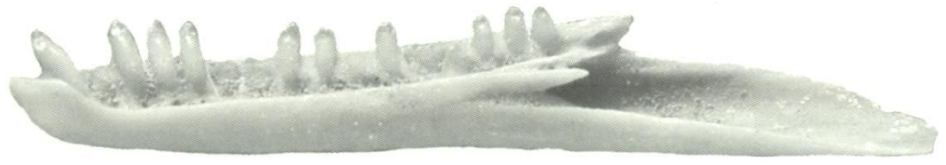

B
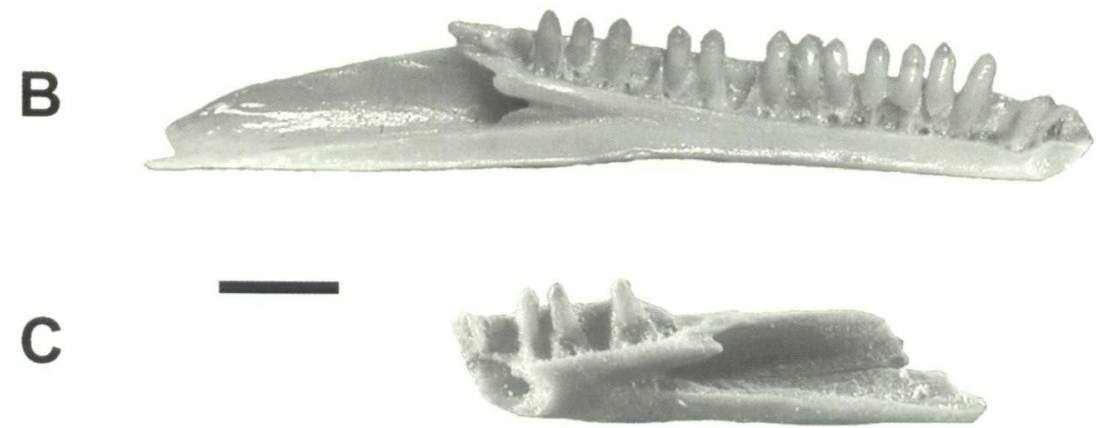

Figure 2 Pygopodid dentaries from mid-Holocene cave deposits. A, Pygopus sp., right dentary (TMM 41209-964) from the 15.0-23.0 cm level (Cal BP 4,120) and B, Pygopus sp., left dentary (TMM 41209-965) from the 30.5$38.0 \mathrm{~cm}$ level in Webbs Cave, WA. C, posterior fragment of a Pygopus sp. right dentary (TMM 41374-1) from the red sand and clay unit at 92-106 cm level in Wombat Cave, SA. Scale equals $1 \mathrm{~mm}$. 
extends well posterior to the coronoid. The intramandibular septum is not extended posteriorly. The fragment contains tooth loci for seven teeth (excluding referral to Aprasia). The splenial is not present but its articulation area is evident and shows that it probably separated the prearticular from the dentary (thus excluding referral to Aprasia, Ophidiocephalus or Pletholax); this feature is found in Delma, Pygopus and Paradelma. The anterior position of the splenial contact on the dentary is ventral to the four posterior-most tooth positions, and thus the specimen cannot represent Aprasia, Ophidiocephalus, or Pletholax, but is consistent with that condition found in Delma, Pygopus and Lialis. Although the posterodorsal area is somewhat damaged on TMM 41374-1, it shows the contact placements for both the labial and lingual projections of the coronoid to be at different elevations in the bone (versus the same elevation found on Delma and Paradelma). Tooth crowns are simple with blunt-pointed, slightly grooved apices, and are not recurved as found on Lialis. This combination of characters suggests that the specimen is a species of Pygopus.

\section{DISCUSSION}

The pygopods are a distinctive element of the modern lizard fauna in Australia. A phylogenetic analysis of pygopods based on mitochondrial DNA, nuclear DNA, and morphological data led Jennings et al. (2003) to support earlier studies that indicated that speciation of mesic-adapted biotas in the southeastern and southwestern corners of the continent occurred largely within those geographic regions between 23 and 12 million years ago as opposed to repeated dispersals between the regions. However, it is not clear whether or not dispersals occurred during cyclic changes from glacial to interglacial regimes of the latest Pliocene and throughout the Pleistocene. Cave sites along the greater Hampton Tableland (such as Webbs and Wombat caves; see others in Baynes 1987) and nearby Nullarbor Plain are positioned to record east-west dispersals (if they occurred) through these climatic cycles. The requirement of a detailed chronology for most of these sites has yet to be attained.

Pygopus was identified from Webbs and Wombat caves on the Hampton Tableland dating to Cal BP 4,160 (and possibly earlier at Wombat Cave). Species of pygopods living in the region today include Aprasia inaurita, Lialis burtonis, Pygopus lepidopodus (likely at the caves today) and $P$. nigriceps (Storr et al. 1990; Wilson and Swan 2003). Based on the known living fauna, and the mid-Holocene age of the remains, it is predictable that some species of Pygopus would be recovered from deposits within Webbs and Wombat caves.
The distance from the coast mostly determines the amount of rainfall on the Hampton Tableland and Nullarbor Plain, which in turn, controls the distribution of vegetation. The three vegetation zones recognized along the region are a mallee scrub zone located nearest to the coast, arid scrub, and a treeless plain found furthest from the coast (Martin 1973). During the mid-Holocene, vegetation patterns of the Nullarbor were broadly similar to those of today, suggesting that the climate of these times was not substantially different. Prior analysis of the recovered pollen from late Quaternary Madura Cave sediments (located $65 \mathrm{~km}$ south and west of Webbs Cave) provides a direct vegetation community reconstruction for the Nullarbor Plain (Martin 1973). We apply the results of that pollen analysis from Madura Cave to Webbs and Wombat caves because of their close proximity and roughly equal distance from the coastline.

Today Webbs and Wombat caves are about $35 \mathrm{~km}$ from the coastline. During glacial maximum, the coastline was approximately $160 \mathrm{~km}$ south of its present position along the Hampton Tableland and Nullarbor south of these caves. With the rise of sea level after the 18,000-15,000 yr B.P. low-stand, the coastline moved closer to the caves. The period between 9,000 and 4,000 yr B.P. was one of dramatic changes in the vegetation mainly in response to an increase in rainfall, and therefore, an increase in the mallee (eucalypt Myrtaceae) scrub community. After that time, the mallee scrub cover declined in abundance, followed by development of the arid scrub to treeless plain seen in the region today (Martin 1973).

Pygopus was differentiated and established in Australia by the Miocene (Hutchinson 1997); however, we do not know when Pygopus moved into the region around Webbs and Wombat caves. Our data document that they were present, if not established, by approximately 4,200 years ago. Both $P$. lepidopodus and $P$. nigriceps live today in the greater Nullarbor and nearby desert areas in mainly low shrubland with sandy soils (Storr et al. 1990; Wilson and Swan 2003).

\section{CONCLUSIONS}

It is interesting that only three dentaries of pygopods were identified from the thousands of bones recovered from both Webbs and Wombat caves. At the generic level, the mid-Holocene fossils are logical discoveries. The recovery of any pygopod remains is significant because all remains help reconstruct the timing for the development of the community mosaic that occurs today. Based on this scant and preliminary record, it appears that at least Pygopus inhabited the communities outside the caves, as they do today, by the middle to late Holocene. 
It is apparent from our studies that a precise, isotopic-based chronology for each of the caves that contain fossil vertebrates is a prerequisite to truly understand the establishment of modern squamate community mosaics. Although this as yet has not been systematically implemented, it is beginning to be put into practice (see Prideaux et al. 2007a,b). Additional Pleistocene deposits with lizard remains are needed to assess the development of the current biotic communities and how the faunas responded to changing climate regimes and other influential factors. Not all paleontological deposits were screened through mesh sieves small enough (less than $500 \mu \mathrm{m}$ ) to recover isolated bones of small lizards. The use of micro-mesh screens is now a consistent practice at select excavations. The ability to reconstruct the development of the modern lizard communities and the community mosaic changes through time for Western and South Australia largely are dependant on the capability to identify accurately the recovered fossils. Ideally the identifications should be based on apomorphies, but that approach requires an extensive collecting and research program geared towards that goal. An important first step is an adequate comparative collection of articulated and disarticulated skeletons, and an appreciation of ontogenetic, sexual and individual variation within each species. Only with such a collection can palaeontologists begin to discover apomorphies in the anatomical systems (i.e. specific disarticulated skeletal elements) that we typically find preserved in the fossil record. Comprehensive skeletal comparative collections and descriptions now are beginning to be produced at the Western Australian Museum and exist at the South Australian Museum. Cranial osteology increasingly is being described for species of Australian lizards; and therefore, further discoveries are expected as the fossil specimens are compared with the known modern morphologies and described apomorphies.

\section{ACKNOWLEDGEMENTS}

We appreciate the help of Paul Doughty, Ric How, Brad Maryan, Claire Stevenson, and the museum administration of the Western Australian Museum for extensive use of their museum facilities and their continued support of our longterm project on modern and fossil lizards of WA. We appreciate the discussions with Mark Hutchinson (South Australian Museum) and Scott Hocknull (Queensland Museum) about lizards and use of their local skeleton collections. Mark Hutchinson provided tremendous insight into lizard osteology and is greatly appreciated. We appreciate the lengthy discussions with Gavin Prideaux (Flinders University) and Emie Lundelius (University of Texas at Austin) about caves and fossil deposits of WA. We thank Bryan Jennings (Harvard University) and Eric Pianka (University of Texas at Austin) for discussions about pygopods. Ernie Lundelius graciously provided copies of his field notes and took the time to discuss his work in WA during the 1950s and 1960s. We appreciate the assistance of Lyndon Murray (University of Texas at Austin) for the curation of the specimens into the Texas Memorial Museum, Vertebrate Paleontology Laboratory. Partial funding for our research was received from the College of Engineering and Natural Sciences, Northern Arizona University. Edits and suggestions to an earlier draft of this manuscript were received from Michael Lee (South Australian Museum), Mark Hutchinson and Paul Doughty; their help is greatly appreciated.

\section{REFERENCES}

Balme, J., Merrilees, D. and Porter, J.K. (1978). Late Quaternary mammal remains, spanning about 30000 years, from excavations in Devil's Lair, Western Australia. Journal of the Royal Society of Western Australia 61: 33-65.

Bauer, A.M. (1990). Phylogenetic systematics and biogeography of the Carphodactylini (Reptilia: Gekkonidae). Bonner Zoologische Monographien 30 $1-218$.

Baynes, A. (1982). Dasyurids (Marsupialia) in late Quaternary communities in southwestern Australia (pp. 503-510). In: Archer, M. (ed.), Carnivorous Marsipials Vol. 2. Royal Zoological Society of New South Wales: Mosman, NSW.

Baynes, A. (1987). The original mammal fauna of the Nullarbor and southem peripheral regions: evidence from skeletal remains in superficial cave deposits ( $p p$. 139-152, 399-401). In: McKenzie, N.L. and Robinson, A. C. (eds), A Biological Survey of the Nullarbor Region South and Western Australia in 1984 Australian National Parks and Wildlife Service: Canberra, ACT.

Bell, C.J., Evans, S.E. and Maisano, J.A. (2003). The skull of the gymnophthalmid lizard Neusticurus ecpleopus (Reptilia: Squamata). Zoological Journal of the Linnean Society 139: 283-304.

Bellairs, A. d'A. and Kamal, A.M. (1981). The chondrocranium and the development of the skull in recent reptiles (pp. 1-263). In: Gans, C. and Parsons, T. C. (eds). Biology of the Reptilia, Volume 11, Morphology F. Academic Press: New York, NY, USA.

Broom, R. (1935). On the structure of the temporal region in lizard skulls. Annals of the Transval Museum 18 13-22.

Camp, C.L. (1923). Classification of the lizards. Bulletin of the American Museum of Natural History 48: 289 481 .

Cope, E.D. (1892). On degenerate types of scapular and pelvic arches in the Lacertilia. Journal of Morphology 7: 223-244, Plate 13.

Donnellan, S.C., Hutchinson, M.N. and Saint, K.M (1999). Molecular evidence for the phylogeny of 
Australian gekkonoid lizards. Biological Journal of the Linnean Society 67: 97-118.

Dortch, J. (1996). Late Pleistocene and recent Aboriginal occupation of Tunnel cave and Witchcliffe Rock Shelter, southwestern Australia. Australian Aboriginal Studies 1996: 51-60.

Dortch, J. (2004). Late Quaternary vegetation change and the extinction of black-flanked rock-wallaby (Petrogale lateralis) at Tunnel Cave, southwestern Australia. Palaeogeography, Palaeoclimatology, Palaeoecology 211: 185-204.

Estes, R., de Queiroz, K. and Gauthier, J. (1988). Phylogenetic relationships within Squamata (pp. 119281). In: Estes, R. and Pregill, G. (eds). Phylogenetic Relationships of the Lizard Families: Essays Commemorating Charles L. Camp. Stanford University Press, Stanford, California, USA.

Etheridge, R. (1967). Lizard caudal vertebrae. Copeia 1967: 699-721.

Etheridge, R. and de Queiroz, K. (1988). A phylogeny of Iguanidae (pp. 283-367). In: Estes, R. and Pregill, G. (eds). Phylogenetic Relationships of the Lizard Families: Essays Commemorating Charles L. Camp. Stanford University Press: Stanford, CA, USA.

Fürbringer, M. (1870). Die Knochen und Muskeln der Extremitäten bei den Schlangenähnlichen Sauriern. Verlag von Wilhelm Engelmann, Leipzig, Germany.

Gans, C. (1978). The characteristics and affinities of the Amphisbaenia. Transactions of the Zoological Society of London 34: 347-416.

Greer, A.E. (1970). A subfamilial classification of scincid lizards. Bulletin of the Museum of Comparative Zoology, Harvard University 139: 151-183.

Greer, A.E. (1989). The Biology and Evolution of Australian Lizards. Surrey Beatty \& Sons, Pty Limited: Chipping Norton, NSW.

Han, D., Zhou, K. and Bauer, A.M. (2004). Phylogenetic relationships among gekkotan lizards inferred from $C$-mos nuclear DNA sequences and a new classification of the Gekkota. Biological Journal of the Linnean Society 83: 353-368.

Hoffstetter, R. and Gasc, J.-P. (1969). Vertebrae and ribs of modern reptiles. In: C. Gans, A. d'A. Bellairs, and T. S. Parsons (eds), Biology of the Reptilia, Volume 1, Morphology A: 201-310, Academic Press: New York, New York, USA.

Hutchinson, M. N. (1997). The first fossil pygopod (Squamata, Gekkota), and a review of mandibular variation in living species. Memoirs of the Queensland Museum 41: 355-366.

Jennings, W.B., Pianka, E.R. and Donnellan, S. (2003). Systematics of the lizard family Pygopodidae with implications for the diversification of Australian temperate biotas. Systematic Biology 52: 757-780.

Jensen, A.S. (1901). Om Ophiopsieps nasutus de Bocage etc. Videnskabelige Meddelelser fra den Naturhistoriske Forening I Kjobenhavn 2: 317-328, Plate 3.

King, M. and Mengden, G. (1990). Chromosomal evolution in the Diplodactylinae (Gekkonidae: Reptilia). II. Chromosomal variability between New Caledonian species. Australian Journal of Zoology 38: $219-226$.
Kinghorn, J.R. (1923). Studies in Australian reptiles. No. 3. Records of the Australian Museum 14: 126-134.

Kinghorn, J.R. (1926). A brief review of the family Pygopodidae. Records of the Australian Museum 15: 40-64.

Kluge, A.G. (1976). Phylogenetc relationships in the lizard family Pygopodidae: an evaluation of theory, methods and data. University of Michigan Museum of Zoology Miscellaneous Publications 152: 1-72.

Kluge, A.G. (1987). Cladistic relationships in the Gekkonoidea (Squamata, Sauria). University of Michigan Museum of Zoology Miscellaneous Publications 173: 1-54.

Lee, M.S.Y. (1998). Convergent evolution and character correlation in burrowing reptiles: towards a resolution of squamate relationships. Biological Journal of the Linnean Society 65: 369-453.

Lundelius, E.L. (1960). Post Pleistocene faunal succession in Western Australia and its climatic interpretation. In: J. Iversen, E. Hyyppä, and S. Thorarinsson (eds), Geochronology and Climatology of the Quaternary: 142-153, International Geological Congress Report of the Twenty-First Session, Norden. Part IV. Proceedings of Section 4. Berlingske Bogtrykkeri: Copenhagen, Denmark.

Lundelius, E.L. (1963). Vertebrate remains from the Nullarbor caves, Western Australia. Journal of the Royal Society of Western Australia 46: 75-80.

Lundelius, E.L. (1983). Climatic implications of Late Pleistocene and Holocene faunal associations in Australia. Alcheringa 7: 125-149.

Maclean, W.P. (1974). Feeding and locomotor mechanisms of teiid lizards: Functional morphology and evolution. Papéis Avulsos de Zoologia 27: 179213.

Martin, H.A. (1973). Palynology and historical ecology of some cave excavations in the Australian Nullarbor. Australian Journal of Botany 21: 283-316.

Maryan, B., Aplin, K.P. and Adams, M. (2007). Two new species of the Delma tincta group (Squamata: Pygopodidae) from northwestern Australia. Records of the Western Australian Museum 23: 273-305.

McDowell, S.B., Jr. and Bogert, C.M. (1954). The systematic position of Lanthanotus and the affinities of the anguinomorphan lizards. Bulletin of the American Museum of Natural History 105: 1-142, Plates 1-16.

Moffat, L.A. (1973). The concept of primitiveness and its bearing on the phylogenetic classification of the Gekkota. Proceedings of the Linnean Society of New South Wales 97: 275-301

Parker, H.W. (1956). The lizard genus Aprasia; its taxonomy and temperature-correlated variation. Bulletin of the British Museum (Natural History), Zoology 3: 365-385.

Prideaux, G.J., Roberts, R.G., Megirian, D., Westaway, K.E., Hellstrom, J.C. and Olley, J.M. (2007a). Mammalian responses to Pleistocene climate change in southeastern Australia. Geology 35: 33-36.

Prideaux, G.J., Long, J.A., Ayliffe, L.K., Hellstrom, J.C., Pillans, B., Boles, W.E., Hutchinson, M.N., Roberts, R.G., Cupper, M.L., Arnold, L.J., Devine, P.D. and 
Warburton, N.M. (2007b). An arid-adapted middle Pleistocene vertebrate fauna from south-central Australia. Nature 445: 422-425.

Rieppel, O. (1984a). The structure of the skull and jaw adductor musculature in the Gekkota, with comments on the phylogenetic relationships of the Xantusiidae (Reptilia: Lacertilia). Zoological Journal of the Linnean Socioty 82: 291-318.

Rieppel, O. (1984b). Miniaturization of the lizard skull: its functional and evolutionary implications. In: M. W. J. Ferguson (ed.), The Structure, Development and Evolution of Reptiles. A Festschrift in Honour of Professor A. d'A. Bellairs on the Occasion of his Retirement. Symposia of the Zoological Society of London 52: 503-520.

Röll, B. and Henkel, F.W. (2002). Are pygopods just legless geckos? Evidence from retinal structures. Salamandra 38: 73-84.

Russell, A.P. and Bauer, A.M. (2002). Underwood's classification of the geckos: A 21 century appreciation. Bulletin of The Natural History Museum, Zoology, 68: 113-121.

Shea, G.M. (1993). Family Pygopodidae (pp. 234-239). In: Glasby, C.J., Ross, G.J.B. and Beesley, P.L. (eds), Fauna of Australia. Vol. 2 A Amphibia \& Reptilia. Australian Government Publishing Service: Canberra, ACT.
Stephenson, N.G. (1962). The comparative morphology of the head skeleton, girdles and hind limbs in the Pygopodidae. The Joumal of the Linnean Society of London (Zoology) 44: 627-644.

Stokely, P.S. (1947). The post-cranial skeleton of Aprasia repens. Copeia 1947: 22-28.

Storr, G.M., Smith, L.A. and Johnson, R.E. (1990). Lizards of Western Australia 1/l. Geckos \& Pygopods. Western Australian Museum, Perth.

Sumida, S.S. and Murphy, R.W. (1987). Form and function of the tooth crown structure in gekkonid lizards (Reptilia, Squamata, Gekkonidae). Canadian Joumal of Zoology 65: 2886-2892.

Underwood, G. (1957). On lizards of the family Pygopodidae. A contribution to the morphology and phylogeny of Squamata. Journal of Morphology 100: $207-268$.

Underwood, G. (1970). The eye. In: C. Gans and T. S. Parsons (eds), Biology of the Reptilia, volume 2, Morphology B: 1-97, Academic Press: New York, New York, USA.

Wilson, S. and Swan, G. (2003). A Complete Guide to Reptiles of Australia. New Holland Publishers, Sydney, NSW.

Manuscript receided 1 November 2007; accepted 19 May 2008. 